Published on Reviews in History (https://reviews.history.ac.uk)

\title{
The Enlightenment as Modernity: Jonathan Israel's Interpretation Across Two Decades
}

Review Number: 2039

Publish date: Thursday, 15 December, 2016

Author: Jonathan Israel

ISBN: 9780199254569

Date of Publication: 2001

Price: $£ 31.99$

Pages: 832pp.

Publisher: Oxford University Press

Publisher url: https://global.oup.com/academic/product/radical-enlightenment-9780199254569?cc=gb\&lang=en\& Place of Publication: Oxford

Reviewer: Thomas Munck

Radical Enlightenment: Philosophy and the Making of Modernity 1650-1750 (Oxford, 2001); Enlightenment Contested: Philosophy, Modernity and the Emancipation of Man 1670-1752 (Oxford, 2006); Democratic Enlightenment: Philosophy, Revolution and Human Rights 1750-1790 (Oxford, 2011); Revolutionary Ideas: an Intellectual History of the French Revolution from the Rights of Man to Robespierre (Princeton, NJ, 2014); A Revolution of the Mind: Radical Enlightenment and the Intellectual Origins of Modern Democracy (Princeton, NJ, 2010)

Professor Jonathan Israel is one of the most distinguished and prolific historians of early modern Europe. During his long career he has published major work on international trade and maritime power, the Dutch revolt against Spain, the broader span of Dutch history over three centuries (1995), the history of European Jews in the early modern period (1985), and the Glorious Revolution of 1688-9. His work has been widely recognised, notably with a professorship at University College London, and since 2001 at the Institute for Advanced Studies in Princeton, from which he has just retired. He has been a long-standing Fellow of the British Academy, has been honoured in Dutch academic circles, and has won a number of international awards and prizes for his books.

Over the last 20 years, Professor Israel has focused almost entirely on the Enlightenment and the origins of modern concepts of democracy, equality and freedom. He started with the pivotal Dutch-Jewish philosopher Baruch Spinoza, but the project developed into a much more expansive analysis of the history of ideas from the 1660s to the revolutions in the western world in the last decades of the 18th century. His work has been presented in a remarkable series of books. Radical Enlightenment: Philosophy and the Making of Modernity 1650-1750 (2001), was followed by Enlightenment Contested: Philosophy, Modernity and the Emancipation of Man 1670-1752 (2006), and Democratic Enlightenment: Philosophy, Revolution and Human Rights 1750-1790 (2011). With over 2500 pages of dense text, these three volumes easily amount to the biggest single-authored interpretation of the Enlightenment since Franco Venturi's massive five-volume study of the Enlightenment from an Italian and comparative European perspective, Settecento riformatore (1969-90). Israel has now rounded off his interpretation in a separate volume of 700 pages, Revolutionary Ideas: an Intellectual History of the French Revolution from the Rights of Man to Robespierre (2014). At 
first sight this book seems to serve a different purpose: intended more for general readers who want a narrative overview of the Revolution, it sets out to understand the ideological battles of the 1790s in the context of an essentially political narrative. The underlying interpretation, however, is clearly based on strands from Democratic Enlightenment, where 1789 was portrayed as an intellectual revolution, and it therefore makes good sense to read Revolutionary Ideas as a sequel to the earlier volumes. Indeed the shorter interpretative overview which Israel provided in a series of Oxford lectures, published as A Revolution of the Mind: Radical Enlightenment and the Intellectual Origins of Modern Democracy (2010), confirms that we are dealing with essentially one very large overall argument.

Professor Israel's achievement over the last 20 years might be summed up from two different perspectives. In terms of scholarly detail, he has brought to light connections between a vast array of writers and thinkers across the whole period, including many whose significance had not hitherto been widely recognised, and whose work had fallen into obscurity. We have gained a much more detailed and fine-grained view of the sheer diversity and intellectual creativity not just amongst those who may have been influenced by Spinoza, but also amongst their critics, and those who may be deemed part of either the moderate Enlightenment or even a Counter-Enlightenment. But in addition, Israel has also offered a full reinterpretation of the Enlightenment as a whole, arguing that it was essentially binary - pitching a small group of radicals (advocating wholly new egalitarian and anti-religious views) against the great majority of moderate writers who sought gradual change and reform. Israel's overall analysis of the Enlightenment has become the focus for a lively and very productive debate amongst historians, but while his overall interpretation has undoubtedly changed general historical perceptions of the origins of democracy and equality in western society, the details of his argument have not escaped critical scrutiny from a number of historians specialising in this field. Many have admired the perseverance and prodigious amount of research that has gone into these volumes, while rejecting Israel's binary view of the Enlightenment, and questioning his use of some of the primary source material. It goes without saying that the short comments that follow, here, cannot possibly do full justice either to Professor Israel's enormous synthesis, or to the detailed and very fruitful scholarly debate that has ensued. Rather, they are an attempt by one historian to reflect on the directions in which Israel's work has taken us over the last twenty years, what impact it has had on Enlightenment research agendas, and whether we are now any closer to understanding the French Revolution as a culmination of Enlightenment radicalism.(1)

The introduction to the fourth volume, Revolutionary Ideas, makes clear that Israel wants a 'big narrative' to replace what he describes as a series of failed interpretations of the Revolution based on class, social tension, economic disarray, failures of government and lack of effective leadership. With characteristic boldness, Israel asserts that an approach based on the history of ideas can indeed provide a durable new interpretation. Readers of the earlier three volumes will not be surprised to find that Israel sees the French Revolution not through the kind of discourse analysis which revolutionary historians have applied with much success since the 1980s, nor through detailed study of the political vocabulary found in the pamphlets, posters, proclamations, newspapers and speeches of 1792-5. Instead, Israel prefers to focus on the ideological radicalism that came to dominate the revolutionary agenda, and in particular on the materialist and democratic arguments derived from Helvetius, d'Holbach, Diderot and Rousseau (seen here as the true heirs of radical philosophy, which in his earlier volumes Israel traced back to Spinoza). He uses his own definition of radical ideology to analyse the emerging divisions between Jacobins and Girondins in 1792, the influence of Condorcet and the Cercle social on democratic thinking, the nature of the relationship between Robespierre and Rousseau, and a number of other issues that affected the course of the Revolution in fundamental ways. The book is indeed a descriptive narrative, interspersed with thematic chapters on the 'war with the church', education, black emancipation, and the wider overspill across Europe right through to the end of the 1790s. Israel largely follows older political histories of the Revolution, but (as in the earlier volumes on the Enlightenment) we also find a generous sprinkling of short quotations from contemporary printed texts, speeches and other material representing a wide range of participants in the Revolution. Inevitably, perhaps, such an approach does not leave much space to respond to newer detailed interpretations of the discordant political cultures and shifting discourses of the Revolution, or to address inconsistencies 
and problems in the grand narrative itself. The bibliography reflects this perspective: it lists a good range of primary sources, but does not take into account as much of the recent work on the Revolution as one might have expected.

An indicative example of Israel's approach is found in his discussion of the all-important newspaper press. He notes (pp.42-8) how many future politicians were active from 1789 onwards publishing newspapers: how for example Brissot's journalism was targeted by more traditional papers, and how Le patriote français established itself as a durable mouthpiece for freedom of the press and constitutional reform. He notes a number of other successful newspaper entrepreneurs, including Prudhomme (Révolutions de Paris), Gorsas ( Courrier), Carra (Annales patriotiques), as well as the more conservative papers published by Royou (L'ami du roi) or Mallet du Pan (Le mercure de France). There were 100s of new titles in the early years of the Revolution, many of them disappearing after a few issues, others surviving even into the years of the Terror. Although a few of these papers are characterised briefly in terms of apparent circulation figures and reputation, we miss substantial analysis of how their editorial strategy evolves, how their language helped to shape revolutionary discourse, or even of who the intended readers may have been. Granted, we will probably never have reliable figures on the actual circulation; but detailed reading of the papers themselves can give significant insights into the rapidly shifting impact of ideas and ideals during each of the critical turning-points of the revolution. Without such analysis of at least a sample of newspaper titles, Israel has to have recourse to familiar generalisations (p. 48) underpinned with a liberal sprinkling of quotations selected on the basis of an unspecified research methodology.

As in his previous volumes, Israel wants to identify those who followed 'radical philosophy', and set them against more conservative or traditionalist writers. He is right to bring in both newspapers and other kinds of printed text. But he tends to let the 'big narrative' of ideas displace fundamental analysis of how textual media actually worked, what effect the collapse of censorship had, and how far the newspapers and pamphlets themselves lacked the precision and specificity needed to educate the broadening political nation. Enough research has been done on at least some of the newspapers to show how much we can learn from more systematic study of the agendas and changing allegiances of some of those whom Darnton once described as 'grub-street' writers, now turned journalists and pamphleteers, responding to successive political crises. For example, characterisation (p.160f) of the more populist newspaper publishers Marat, Hébert and Jumel suggests they initially refused to take sides between monarchists and democrats, 'preferring instead to build up their own excitable, panicky, illiterate, and volatile following by using sensation, theatrical exaggeration, and rumour-mongering'. Maybe so, but such a sweeping statement needs to be backed up by substantive analysis (and certainly more than the sparse older material cited in footnotes). If we are to accept that the newspapers really exercised a crucial influence (as critics of Marat and Hébert argued, at the time), closer scrutiny both of the texts and of their precise location in the political culture of the Revolution would have been helpful.

However, it may not be entirely fair to quibble over detail: after all, no general synthesis of a period as complicated as the French Revolution can do full justice to either the wealth of source material or the richness of detailed research done by specialists. So we may prefer to ask broader questions. Does an 'intellectual history of the French Revolution' work, when built on the foundations of a political grand narrative? Can the history of ideas provide a satisfactory new overall synthesis to displace what Israel dismissed at the start as the failed interpretations of existing scholarship? Or if we want to focus on something more specific, do we get insights into the emergence of concepts of 'rights of man', as signalled in the subtitle of this book? Searching the quite detailed index for relevant keywords, we find no generic entry to locate discussions of emerging ideas on rights: instead, there are sub-entries for Tom Paine's Rights of Man (under his name), and several entries for 'women's rights'. So we turn to chapter four, entitled 'The Rights of Man: summer and autumn 1789'. It discusses the August decrees, the Declaration of Rights of 26 August, and the constitutional issue of the royal veto. Israel notes that trained lawyers from the Parlements were excluded from the key committees working up draft declarations (p. 72f), and suggests the main input was from what he calls 'the parti de philosophie', egged on by general denunciations of privilege in the press and in the assembly. We hear of the rhetoric of Sieyes, Mirabeau, Barnave, and others who were expert at 
playing to the galleries for as long as they had the initiative. The text of the Declaration of Rights, we are told (p. 77), was thrashed out by the constitutional committee of eight who adopted the 'revolutionary terminology of the democratic Enlightenment' and of natural rights. Condorcet's draft quickly disappeared in the arguments, whilst American precedents were deemed too undemocratic. Israel also observes how the assembly's discussion of the Declaration took weeks, often muddied by counter-proposals and by the confrontation between those who wanted less 'metaphysics' and those who wanted to secure a more traditional and legally valid text. The final text owed much to what is described as 'the radical bloc' (including Mirabeau, Condorcet and Pétion, as well as Sieyes), but whether these really had a coherent narrative is understandably left as an open question. Israel rightly observes how controversial even the very short 17-clause agreed Declaration was, both within the Assembly, in France generally, and abroad. Disagreements which had emerged during this drafting process were soon transferred to the detailed discussion of the rest of the Constitution, splitting up whatever tactical alliances may have been formed amongst leading radicals during the summer of 1789. It is not surprising, therefore, to find another round of confrontations and tactical manoeuvres in the drafting of the second, much more democratic declaration of rights in 1793, where Condorcet again provided a version which did not secure consensus.

The constantly shifting personal contacts, temporary networks and recurrent rows amongst the many revolutionary activists provide Israel with a rich seam of material. With the help of the index, we can follow the rapidly evolving revolutionary career of a large cast of participants, including both familiar and more marginal participants. Key turning points, such as those during the late summer of 1792, can thus be revisited in terms of major revolutionary concepts, through the role of individuals, or, sometimes, in collective crowd action. The rapid success of the journée of 10 August is described in terms of the lack of effective conservative or Feuillant leadership, the manifest weaknesses in the monarchist constitutional compromise, and above all the action of a small group of revolutionary activists - leaving both the great majority of the Legislative Assembly and the larger Paris crowd (outside the Commune leadership) mostly passive bystanders, endorsing change after it had happened. We see Desmoulins and Pétion as active participants in the events of 9-10 August, but are given no new explanation of why Marat and Robespierre were invisible, despite their contacts in the Paris Commune. We note that universal male suffrage was soon declared as a new core principle in line with fundamental human rights - though precisely where this idea came from remains unclear.

A fuller account is given of the prison massacres of 2-6 September, where Marat's complicity is made clear on the basis of his printed exhortative circular to other départements. But evidence regarding the crucially moderating if ambiguous role played by Danton (as minister of justice and leader of the provisional council) is not analysed, nor the intriguing account later provided by observers such as Louis-Philippe. We may also look for a close analysis of the motivations and ideas behind Louvet's bold and ferocious attack on Robespierre, in the new Convention, on 29 October 1792, where he summed up accusations of vote-rigging and manipulation in the Paris Commune. But here we are faced with another problem inherent in a narrative approach: Louvet is at this point grouped together with others, generally labelled as Girondins, including Condorcet and Vergniaud. But it is difficult to imagine revolutionary orators more different in approach than Louvet (an impulsive and outspoken revolutionary in pursuit of a visionary republic) and Vergniaud (a highly regarded lawyer seeking a political order determined by legal principles). Constructing political groups on the basis of a few short quotations, and without new background research, does not make for a solid analysis of the many fracture lines in revolutionary politics. Robespierre, represented in his familiar role, continues to take much of the blame, but we find no new insights into his beliefs or principles: judging from the footnotes - and as we would expect - Israel has dug bravely into the interminable speeches and much more laconic letters and memos that might give clues to what ideas really kept Robespierre going, but the fast-moving narrative barely pauses.

Standing back, we may now be entitled to ask whether a persuasive new interpretation is offered, in Revolutionary Ideas, to replace the existing explanatory frameworks for the Revolution which Israel dismissed at the start. As he closes this volume, he boldly states (p. 695) that 'The French Revolution, we may conclude was really three revolutions - a democratic republican revolution, a moderate Enlightenment 
constitutional monarchism invoking Montesquieu and the British model as its criteria of legitimacy, and an authoritarian populism prefiguring modern fascism'. Whether such a conclusion is fully supported in this volume, in terms of the analysis, the evidence, or the research strategy, will undoubtedly focus the minds of historians of the Revolution for years to come. But as Jonathan Israel himself explains in the last pages of this book, he has unquestionably tied the Revolution firmly to his long-running analysis of the Enlightenment. In so doing, he has also helped to rescue the radical heritage of Diderot and Condorcet from the wreckage of the Revolution, and by extension, has located Robespierre and Saint-Just more firmly on the violent, populist and intellectually irresponsible margins.

Each of the earlier three volumes on the Enlightenment have been reviewed extensively on their own, so we may now wish to explore how well Israel's history of ideas works across the whole span from 1670 to 1799. No one will dispute that Israel's bold attempt to identify a 'radical Enlightenment' has created fertile ground for debate. The concept was explored earlier (for example by Margaret C. Jacob), but the central role which Israel allocates to Spinoza and a small group of like-minded thinkers has made us think afresh about what the Enlightenment was about. Throughout all four volumes, Israel successfully identifies writers who have not previously been fitted into a grand narrative, and some that have been considered entirely marginal. The first volume, Radical Enlightenment, not only provides a richly illuminating study of Spinoza's work, his context and circle of friends, but also follows the underground life of his books and ideas from after his death well into the early eighteenth century. Enlightenment Contested covers much the same period, but focuses on the Enlightenment as a whole, including moderates and conservatives. The third volume, Democratic Enlightenment, concentrates on the forty years after 1750, tackling the revolutions on both sides of the Atlantic (in the case of Francem, to 1790). Along the way we find insights into the deep divisions amongst the French philosophes, which came to light during the battle of the Encyclopédie in the 1750s, and we have illuminating discussion of Voltaire and of key works such as Raynal's monumental History of the two Indies. With his characteristic eye for the unexpected, Israel takes us past a host of other writers, and adds both European and even global comparative perspectives. Given the scope of these middle volumes, it is perhaps understandable that Israel is at times over-stretched. For example, programmes of state reform ('enlightened absolutism' in the ancien régime) are tackled both in Enlightenment Contested and in Democratic Enlightenment, but the line of argument is not always clear, and the diversity and complexity of these reform movements and their intellectual inspiration is at times misunderstood because recent research has not been taken into account. The fourth volume, Revolutionary Ideas, once more makes France the focal point, examining the 1790s consistently from the perspective of a confrontation between radical and moderate Enlightenments. Israel has thus fulfilled his ambition (indicated already in Radical Enlightenment) of applying his thesis across the whole 18th century, and thereby given new life to the very old argument that the Enlightenment culminated in (if not actually causing) the Revolution. 
Such a grand narrative, however, comes at a price. When we are dealing with the transmission of ideas, it is notoriously difficult to demonstrate specific influences, except in the rare instances where the recipient explicitly cites sources. After all, in the lively and many-sided debates and discussion that we see reflected in both print and manuscript in the 18th century, ideas were freely appropriated, modified, self-censored and internalised to such an extent that intellectual ownership and originality becomes difficult to unravel. Israel's earlier volumes were criticised for finding 'spinozism' in some unlikely places - and indeed of attributing to Spinoza certain notions (for example demands for women's emancipation) which can barely be detected from an objective reading of the original text. In any case, Spinoza was himself influenced by the huge spectrum of radical thought uncovered during the English Civil War and Commonwealth (a major dimension which is totally omitted from these volumes). There is also a risk that we read too much 'modernity' into those writers and polemicists who seem radical for their time - and once you start grouping writers in terms of how far they conform to a set of criteria defined by hindsight, the risks of distortion are even greater. Condorcet, for example, would certainly have known some of Spinoza's writings, but one might question whether his great proposals for educational reform, say, or his real interest in gender equality, can be traced back, at all convincingly, to any one originator. He and his wife were both extraordinarily creative thinkers, and their lively interaction (as well as that of their exceptional salon) surely defies reductionism.

Throughout all four volumes, a sharp distinction is made between true radicals and the more moderate adherents of mainstay enlightenment. Enlightenment Contested closed with a postscript in which Israel defined radical Enlightenment in terms of a number of key positions, including firm commitment to philosophical reason, universal equality, toleration, freedom of expression, and republicanism, alongside rejection of supernatural intervention and acceptance of natural principles of ethics. To establish which philosophers, writers and activists would count, we require detailed scrutiny of their system of thought (if they had such a system at all). It takes a bold historian to make grand arches out of ideas and their interpretation, when detailed research on the corpus of publications of so many of the even the major Enlightenment writers is still very incomplete. A grand narrative may be hugely beneficial in highlighting gaps in our research, and encouraging new work. But it also risks oversimplifying and categorising individuals who had complex, and sometimes changeable, systems of ideas which we either do not fully understand or which were never in fact consistent at all.

For a start, we need much closer attention to the real processes of dissemination and reception of ideas - not just questions of the 'public sphere' and public opinion, but also a clearer understanding of the mechanics of the book trade, the processes of critical and uncritical reading by a rapidly growing 'public' (as in the unknown publikum to whom authors often commended their books), and how these texts might inform discussions in reading societies, salons, commercial lending libraries, coffee-houses, the theatre, and in street 'soap-box' oratory. Huge strides have been taken in all these fields in recent years, and have added immeasurably to our understanding of the wider impact of the Enlightenment.

To take just one crucial component, the printing industry itself: the 'history of print', as it has now become, involves a number of intertwined strands. We need to understand how a given text itself emerged, through drafts, corrections, pre-printing manuscript copies sent to friends, post-printing revisions to form new editions - not to mention translations, adaptations, plagiarisms, and many other variants. Very few Enlightenment texts are in any meaningful sense definitive or final, and as we also now know, not even a single edition can be guaranteed to have remained unchanged during one print-run. Detailed research can yield magnificent results, as for example Noel Malcolm has demonstrated in his wonderful edition of Hobbes' Leviathan.(2) For many other major writers the groundwork remains to be done: we still lack, for example, a detailed examination of the many contemporary editions of David Hume's essays, and precisely how they were reshaped and expanded during his lifetime. We also need to map out how they were reviewed, which ones were translated into French and into other languages, how these translations were adapted to suit their new readers (as was accepted practice in the 18th century), and how well the translations themselves fared. The most famous example of distorted translation is the first French version of Beccaria's Dei delitti e delle pene, which not only affected subsequent Italian versions (there were 25 printings in 
Italian by the time the French Revolution broke out), but also caused major problems for the German, English, Dutch and Danish translators, not all of whom knew Italian well enough to be able to put their French version aside.

The history of print does not stop there, of course. What happens to a text in the actual printing workshop matters, as do market forces, supply and demand, pricing, physical lay-out on the page, quality and supply of paper and of type, distribution, publicity, attempts at censorship and suppression (if applicable), not to mention sheer accident or wilful misunderstanding. All of this can tell us a great deal about a particular text, its life after it was released by the author, and the (often unexpected) ways its core ideas may have been absorbed or discarded. Robert Darnton first made us aware of the 'grub street' dimension of the Enlightenment 50 years ago, and his path-breaking work has encouraged many others to come to grips with the dissemination of ideas in altogether new and more diverse ways. As we know all too well, communication and dissemination is as much about the media as about the message, and a convincing new intellectual history has to take the whole process of communication and dissemination into account. Books, journals, newspapers, handbills, sermons, proclamations, letters, manuscript, private diaries, and all other kinds of 'text', were not just means of communicating ideas: they were also physical objects. The material culture of print is now a major area of research, and will undoubtedly profoundly change our understanding of the Enlightenment. It will certainly help to place individual texts, ideas and authors in a clearer historical context.

Research on the Enlightenment has come a long way in recent years, and shows no sign of drying up. If that in turn leads us to question or discard an explanatory framework built primarily around a hard separation of radical and moderate Enlightenment, so be it: we will in any case have gained a much fuller understanding of the literary and intellectual underground, whose complexity and diversity increasingly suggests that the Enlightenment has to be defined more broadly than we once thought. That Israel's enormous work, over 20 years, has raised as many questions as it has answered is itself a great achievement. We may have to abandon attempts to understand the French Revolution by means of a single explanatory framework. But we may now also begin to understand the Enlightenment better as an open-ended discussion, a process of rational questioning, which to participants and modern observers alike created infinite scope for attention to detail, for intellectual exploration that defies easy categorisation, for public discussion, and sometimes for irreparable disagreement.

\section{Notes}

1. I am grateful to Professor Hamish Scott for helpful comments on a draft version of this paper, but the views expressed here are entirely my own.

2 Thomas Hobbes, Leviathan, ed. Noel Malcolm (Oxford, 2012). Back to (1)

Source URL:https://reviews.history.ac.uk/review/2039

\section{Links}

[1] https://reviews.history.ac.uk/item/163448 